\title{
Salinity tolerance of Dodonaea viscosa L. inoculated with plant growth- promoting rhizobacteria: assessed based on seed germination and seedling growth characteristics
}

\author{
Sonia Yousefi ${ }^{1}$, Davoud Kartoolinejad ${ }^{1}$, Mohammad Bahmani ${ }^{2}$, Reza Naghdi ${ }^{3 *}$ \\ ${ }^{1}$ Department of Arid Land Forestry, Faculty of Desert Studies, Semnan University, Semnan, Iran \\ ${ }^{2}$ Young Researcher and Elites Club, Science and Research Branch, Islamic Azad University, Tehran, Iran \\ ${ }^{3}$ Department of Engineering of Wood and Paper Industries, Faculty of Natural Resources, Semnan University, \\ Semnan, Iran
}

\begin{abstract}
Yousefi, S., Kartoolinejad, D., Bahmani, M., Naghdi, R., 2017. Salinity tolerance of Dodonaea viscosa L. inoculated with plant growth-promoting rhizobacteria: assessed based on seed germination and seedling growth characteristics. Folia Oecologica, 44: 20-27.

The study was conducted to evaluate the potential of different strains of plant growth-promoting rhizobacteria (PGPR) to reduce the effects of salinity stress on the medicinal hopbush plant. The bacterium factor was applied at five levels (non-inoculated, inoculated by Pseudomonas putida, Azospirillum lipoferum + Pseudomonas putida, Azotobacter chroococcum + Pseudomonas putida and Azospirillum lipoferum + Azotobacter chroococcum + Pseudomonas putida), and the salinity stress at six levels: $0,5,10,15,20$, and $50 \mathrm{dS} \mathrm{m}^{-1}$. The results revealed that Pseudomonas putida showed maximal germination percentage and rate at $20 \mathrm{dS} \mathrm{m}^{-1}$ ( $18.33 \%$ and 0.35 seed per day, respectively). The strongest effect among the treatments was obtained with the treatment combining the given 3 bacteria at $15 \mathrm{dS} \mathrm{m}^{-1}$ salinity stress. This treatment increased the root fresh and dry weights by $31 \%$ and $87.5 \%$, respectively (compared to the control). Our results indicate that these bacteria applied on hopbush affected positively both its germination and root growth. The plant compatibility with the three bacteria was found good, and the treatments combining Pseudomonas putida with the other one or two bacteria discussed in this study can be applied in nurseries in order to restore and extend the area of hopbush forests and akin dry stands.
\end{abstract}

\section{Keywords}

arid lands, germination characteristics, growth-promoting bacteria, hopbush, saline soils

\section{Introduction}

PGPR (plant growth-promoting rhizobacteria) belong to a heterogeneous group of rhizosphere bacteria enhancing plants growth performance through one or several specific mechanisms. In fact, they represent a diverse group of soil free-living bacteria (GLICK et al., 2007; SENGUPTA et al., 2015). Today, the researchers state that the main PGPR mechanism promoting growth in plants is the bacterial synthesis of Indole-3-acetic (IAA) plant hormone and bacterial adjustment of ethylene production in juvenile seedlings (BASHAN and DE-BASHAN, 2010; SenguPta et al., 2015). Therefore, PGPR leads to an enhanced root area, higher potential to plant nutrients uptake, more variation in root morphology, and subsequently more vigorous plant growth. Plant inoculation with bacteria capable to produce ACC deaminase can reduce stress-induced ethylene production in plants and diminish its adverse effects under stress conditions. Bacteria with such capability can protect plants against

\footnotetext{
*Corresponding author:

e-mail: reza_naghdi@semnan.ac.ir
} 
the harmful impacts of ambient stress such as induced by heavy metals, submersion, plant pathogens, drought, and salinity (BeLimov et al., 2005; KANCHANA et al., 2014; Sengupta et al., 2015).

Although salinity stress may occur in all the stages of the plant growth, it can be seriously harmful for plants during their seedling stage, considering the fact that the initial plant establishment is determinative for its final performance (GLICK et al., 2007; MunNS and TESTER, 2008). Salinity affects seed germination and growth by reduction of water potential, by toxicity of particular ions including sodium and chlorine as well as by reduction of nutritive ions needed for plants such as calcium and potassium (MUNNS and TESTER, 2008). One of the ways how to resist salinity in plants is to inoculate them with growth-promoting bacteria (GLICK et al., 2007) including various kinds of soil bacteria such as Azotobacter, Acetobacter, Azospirillum, Bacillus, and Pseudomonas (SAleEm et al., 2007; SEngupta et al., 2015).

Dodonaea viscosa L. (Hopbush shrub) is a species of Sapindaceae family, native to many tropical and subtropical countries, in particular Australia. The leaves are used to treat rheumatism, gout, stomach ulcers, hermorrhoids, inflammation, and fractures (RAJAMANICKAM et al., 2010). Also, the mentioned species is known to have distinct antidiabetic properties (AHMAD et al., 2012; MuthukUMran et al., 2001). The given species is one of the shrub species found in the semiarid regions of southern Iran, and in many tropical and sub-tropical countries in the world; however its reproduction in natural habitats has faced substantial problems, which caused that the establishment of the men- tioned species seedlings has dramatically decreased (YousEFI et al., 2017). On the other hand, to the best of our knowledge, there is no documented paper in the existing literature reporting the role of PGPR bacteria (in individual and combined forms) on hopbush species' germination under salinity stress. Thus, the present study was conducted to evaluate the success rate of these bacteria in reducing the adverse effects of salinity stress on hopbush seed germination stage.

\section{Materials and methods}

This research was carried out in 2015 to investigate the effects of PGPR on hopbush seed germination characteristics, using factorial experiment under completely randomized design (CRD) with 4 replications. The bacterium factor was applied at five levels: non-inoculated (control), inoculated by Pseudomonas putida strain 169, Azospirillum lipoferum + Pseudomonas putida, Azotobacter chroococcum + Pseudomonas putida, and Azospirillum lipoferum + Azotobacter chroococcum + Pseudomonas putida. The inocula used in this research were endemic to the soils of Iran, which were identified, screened, and purified by the Soil biology department of Iran's Soil and Water Research Institute. The second factor studied was salinity stress applied at 6 levels $(0$, $5,10,15,20$, and $\left.50 \mathrm{dS} \mathrm{m}{ }^{-1}\right)$. The sample seeds were randomly collected from a planted hopbush stand located in Malagha village, Baghmalek, Khouzestan province, Iran (Table 1).

To conduct the experiment, the hollow and imper-

Table 1. Seed characteristics and provenance information of Dodonaea viscosa

\begin{tabular}{ccccccc}
\hline Provenance & $\begin{array}{c}\text { Geographic } \\
\text { coordination }\end{array}$ & $\begin{array}{c}\text { Elevation } \\
(\mathrm{m})\end{array}$ & $\begin{array}{c}\text { Purity } \\
(\%)\end{array}$ & $\begin{array}{c}\text { Weight of } 1,000 \\
\text { seeds }(\mathrm{g})\end{array}$ & $\begin{array}{c}\text { Number of pure } \\
\text { seeds per kg }\end{array}$ & $\begin{array}{c}\text { Moisture } \\
\text { content }(\%)\end{array}$ \\
\hline $\begin{array}{c}\text { Malagha village, } \\
\text { Khouzestan province, } \\
\text { Iran }\end{array}$ & $\begin{array}{c}31^{\circ} 35^{\prime} 07^{\prime \prime} \mathrm{N} \\
50^{\circ} 00^{\prime} 51^{\prime \prime} \mathrm{E}\end{array}$ & 994 & 100 & 10.27 & 97,371 & 6.2 \\
\hline
\end{tabular}

fect seeds were removed from the intact ones. Different pre-treatments were carried out, with using sulfuric acid and boiling water. Among these, sulfuric acid treatment for $30 \mathrm{~min}$ was found to be optimal for breaking the physical seed dormancy. Thus, all the screened seeds were first immersed in concentrated sulfuric acid (98\%) for $30 \mathrm{~min}$ and then rinsed in distilled water thrice. The seeds were disinfected with Carboxin Tiram $\left(2 \mathrm{~g} \mathrm{l}^{-1}\right)$, a fungicide solution, for $3 \mathrm{~min}$ and thoroughly rinsed in distilled water once more (NouRMOHAMMADI et al., 2016).

\section{Seeds rhizobacterial inoculation}

After rinsing with distilled water, the seeds were completely impregnated and turned sticky with a Arabian gum solution (2\%) allowing to adhere the applied bacteria to the seeds. The sticky seeds were inoculated under darkness with a $10 \mathrm{ml}$ growth-promoting rhizobacterial inoculum in both simple (individual) and combined manners (Noumavo et al., 2013; YousEFI et al., 2017). After the seeds had been inoculated by the intended bacteria, salt solubilisation was carried out in order to simulate salinity stress $(\mathrm{NaCl})$. 
After calculating the $\mathrm{NaCl}$ amount needed for each salinity stress level, $3 \mathrm{ml}$ volumes of the intended salt solutions were added to the Petri dishes containing the inoculated seeds. All the treated seeds were placed in parafilm-sealed Petri dishes, with a diameter of $6 \mathrm{~cm}$, with two filter paper layers (25 seeds per a treatment with 4 replications). Deionized water was added to each Petri dish if needed. In order to avoid fungal infection in Petri dishes, Wattman filter papers were replaced every 3 days (RAhimi et al., 2016). Three $\mathrm{ml}$ of $\mathrm{NaCl}$ solution and $3 \mathrm{ml}$ of distilled water were added to Petri dishes containing the treated and untreated seeds, respectively. The Petri dishes were then placed in to a germinator under a constant temperature of $20{ }^{\circ} \mathrm{C}$ and a $65 \%$ relative humidity with a photoperiodic regime of $16 \mathrm{~h} \mathrm{light} / 8$ $\mathrm{h}$ dark at 1,000 lux fluorescent light and studied for a period of 30 days (RAHIMI et al., 2016).

The germination was specified when the emergent radical reached $2 \mathrm{~mm}$ length. After no progressing seed germination was observed in 3 consecutive days, the seeds were removed from the germinator and counted (on around the $21^{\text {st }}$ day).

\section{Measurement of seed and seedling characteristics}

At the end of germination period, the root and stem fresh weights were measured immediately $(0.0001 \mathrm{~g}$ precision), using a linear scale. The root and stem lengths were measured with Image tools 2.0 software after the samples in the Petri dishes were photographed. For measuring dry biomass, the roots and stems were separated from their collar parts, wrapped with a foil, and placed in an oven at $65{ }^{\circ} \mathrm{C}$ for 48 hours and weighted again in the dry state (Haghighi and DA SiLva, 2014). Ultimately, the percentage, rate, the average germination time and seed vigour index were calculated using the equations presented in Table 2.

Table 2. Calculation methods for seed germination characteristics of Dodonaea viscosa

\begin{tabular}{ccc}
\hline Germination characteristics & Calculation method & Reference \\
\hline Germination percentage & $\mathrm{GP}=(n / N) \times 100$ & PANWAR and BHARDWAJ (2005) \\
Germination rate & $\mathrm{GR}=\sum\left(n_{i} / t_{i}\right)$ & PANWAR and BHARDWAJ (2005) \\
Mean germination time & $\mathrm{MGT}=\sum\left(n_{i} \times t_{i}\right) / \sum n$ & KULKARNI et al. (2007) \\
Seed vigour index & $\mathrm{SVI}=\mathrm{GP} \times$ Mean $(\mathrm{Sl}+\mathrm{Rl}) / 100$ & BIRADAR et al. (2010) \\
\hline
\end{tabular}

GP, germination percentage; $n$, number of germinated seeds per day; $N$, total number of seeds; GR, germination rate; $n_{i}$, number of germinated seeds between scoring intervals; $t_{i}$, number of days since the test was started; MGT, mean germination time; SVI, seed vigour index; Sl, shoot length; Rl, root length.

\section{Statistical analysis}

The data were tested for normality and homogeneity of variances, using Kolmogorov-Smirnov and Levene tests, respectively, and subsequently they were subject to a two-way analysis of variance (ANOVA). The differences between the means were compared with the Tukey's test. All statistical analyses were done with the aid of a SPSS software.

\section{Results}

The results of Two-Way ANOVA indicated that the effects of inoculation with Pseudomonas putida strain 169, Azospirillum lipoferum + Pseudomonas putida, Azotobacter chroococcum + Pseudomonas putida, and Azospirillum lipoferum + Azotobacter chroococcum + Pseudomonas putida on all the seed germination characteristics and growth parameters of hopbush seedlings were statistically significant (Table 3 ).

The comparison between the means (Fig. 1) revealed that the growth rate and biomass decreased with increasing salinity level; on the other hand, they were promoted by bacteria application. The germination occurred at $50 \mathrm{dS} \mathrm{m}^{-1}$ salinity stress level; however, the corresponding parameters were not measured due to the stopped seedling growth.

\section{Germination percentage and rate}

The germination percentage and rate decreased with increasing salinity (Fig. 1). At 20 and $50 \mathrm{dS} \mathrm{m}^{-1}$, the control samples' germination percentage was lower than that of the treated species, and Pseudomonas putida treatment showed the highest germination percentage at $20(18.33 \%)$ and $50(8.33 \%) \mathrm{dS} \mathrm{m}^{-1}$. Equally, the maximal germination rate at 20 and $50 \mathrm{dS} \mathrm{m} \mathrm{m}^{-1}$, being 0.35 and 0.17 seed per day, respectively, was obtained with Pseudomonas putida treatment.

\section{Mean germination time and seed vigour index}

The results revealed that the combined treatment with Azospirillum lipoferum + Azotobacter chroococcum + Pseudomonas putida applied on the hopbush seeds under 20 and $50 \mathrm{dS} \mathrm{m}^{-1}$, induced reductions in their mean germination time by $75.7 \%$ and $64.9 \%$, respectively, compared to the control (Fig. 1). Also, the results rela- 
tive to the seed vigour index indicate that the combined treatment comprising all 3 bacteria studied had the highest effect at $15(0.3)$ and $20(0.077) \mathrm{dS} \mathrm{m} \mathrm{m}^{-1}$, compared to the control.

Table 3. The results of ANOVA (mean square values) related to the effect of plant growth promoting rhizobacteria and salinity stress on seed and seedling characteristics of hopbush

\begin{tabular}{cccccccc}
\hline & df & GP & GR & MGT & SVI & SL & RL \\
\cline { 2 - 8 } Bacteria & 4 & $667.36^{* *}$ & $1.08^{* *}$ & $19.85^{* *}$ & $1.40^{* *}$ & $0.89^{* *}$ & $0.68^{* *}$ \\
Salinity & 5 & $19,743.61^{* *}$ & $19.98^{* *}$ & $32.82^{* *}$ & $82.18^{* *}$ & $32.84^{* *}$ & $19.16^{* *}$ \\
Bacteria $\times$ Salinity & 20 & $189.80^{\text {ns }}$ & $0.31^{* *}$ & $7.79^{\text {ns }}$ & $0.36^{\text {ns }}$ & $0.80^{* *}$ & $0.27^{* *}$ \\
Error & 60 & 141.15 & 0.12 & 6.45 & 0.35 & 0.24 & 0.12 \\
\hline & $\mathrm{df}$ & $\mathrm{SFW}$ & $\mathrm{SDW}$ & $\mathrm{RFW}$ & $\mathrm{RDW}$ & $\mathrm{RL} / \mathrm{SL}$ & $\mathrm{RDW} / \mathrm{SDW}$ \\
\cline { 2 - 8 } Bacteria & 4 & $1.71 \times 10^{-5^{*}}$ & $4.28 \times 10^{-7^{* *}}$ & $1.98 \times 10^{-6^{* *}}$ & $7.54 \times 10^{-8^{* *}}$ & $0.202^{* *}$ & $0.045^{*}$ \\
Salinity & 5 & $0.001^{* *}$ & $1.32 \times 10^{-5^{* *}}$ & $0.000^{* *}$ & $2.88 \times 10^{-6^{* *}}$ & $3.07^{* *}$ & $1.20^{* *}$ \\
Bacteria $\times$ Salinity & 20 & $2.17 \times 10^{-5^{* *}}$ & $5.50 \times 10^{-7^{* *}}$ & $2.85 \times 10^{-6^{* *}}$ & $6.49 \times 10^{-8 \mathrm{~ns}}$ & $0.07^{* *}$ & $0.04^{* *}$ \\
Error & 60 & $7.92 \times 10^{-6}$ & $1.49 \times 10^{-7}$ & $1.16 \times 10^{-6}$ & $4.21 \times 10^{-8}$ & 0.30 & 0.19 \\
\hline
\end{tabular}

**Statistically significant at $99 \%$ confidence level; *statistically significant at $95 \%$ confidence level; ns, not significant. GP, germination percentage; GR, germination rate; MGT, mean germination time; SVI, seed vigour index; SL, stem length; RL, root length; SFW, stem fresh weight; RFW, root fresh weight; SDW, stem dry weight; RDW, root dry weight.

\section{Stem and root length}

Stem length increase promoted by the combined treatment Azospirillum lipoferum + Azotobacter chroococcum + Pseudomonas putida at $15 \mathrm{dS} \mathrm{m}^{-1}$ was $79.7 \%$ (compared to the control), at $20 \mathrm{dS} \mathrm{m}^{-1}$, this treatment showed maximal effect on stem length (Fig. 1). Considering the results obtained for roots, the combined treatment of the 3 bacteria had the highest effects at 15 and $20 \mathrm{dS} \mathrm{m} \mathrm{m}^{-1}$, as the root length increased by $242 \%$ (compared to the control) at $15 \mathrm{dS} \mathrm{m}^{-1}$.

\section{Fresh and dry weight of stems}

All the treatments enhanced the fresh stem weight; especially for higher stress levels the evidence followed from the means comparison (Fig. 1), and the maximal effect corresponded to the combined treatments, such that the combined treatment of the 3 bacteria brought about a $12 \%$ increase at $15 \mathrm{dS} \mathrm{m}^{-1}$ compared to the control. At $10 \mathrm{dS} \mathrm{m}^{-1}$ Pseudomonas putida treatment and at $15 \mathrm{dS} \mathrm{m}^{-1}$ the combined treatment improved the dry weight of stem by $50 \%$ and $40 \%$, respectively, compared to the control. Furthermore, the mentioned treatment showed the highest dry stem weight at $20 \mathrm{dS} \mathrm{m}^{-1}$.

\section{Fresh and dry weight of roots}

All the treatments at all levels of salinity stress enhanced the fresh weight of roots over the control. The combined treatment with Azospirillum lipoferum + Pseudomonas putida at $10 \mathrm{dS} \mathrm{m}^{-1}$ and the combined treatment with applying all 3 studied bacteria at $15 \mathrm{dS}$ $\mathrm{m}^{-1}$ improved the fresh weight of roots by $186.36 \%$ and $31 \%$, respectively, as compared to the control. The dry weight of roots increased also as a result of inoculation with the studied growth-promoting bacteria, particularly at higher stress levels. The results of means comparison indicated that the combined treatment with Azospirillum lipoferum + Azotobacter chroococcum + Pseudomonas putida increased the dry weight of roots at 15 and $20 \mathrm{dS} \mathrm{m}^{-1}$. The dry weight of roots increased by $87.5 \%$ at $15 \mathrm{dS} \mathrm{m}^{-1}$, and although the roots of control samples showed no growth at $20 \mathrm{dS} \mathrm{m} \mathrm{m}^{-1}$, the samples inoculated with the given bacteria had a dry weight of $0.1 \mathrm{mg}$ (trace amount of growth).

\section{Discussion}

Novel methods for biocontrol have recently been developed with the aim to protect plants against salinity stress. These methods concern seed and seedling treatment with using plant growth-promoting rhizobacteria (YUE et al., 2007), such as symbiotic bacteria capable to attach root systems and promote their absorption of ambient nutrients necessary for plants growth, development, and stress resistance (ABBAS-ZADEH et al., 2010). Bacteria such as Azotobacter and rhizobacteria have been reported increasing plant height and regeneration through production and synthesis of phytohormones (ABBAS-ZADEH et al., 2010; Kanchana et al., 2014). In the present study, the increase in salinity level from 10 to $50 \mathrm{dS} \mathrm{m}^{-1}$ led to a drastic quality drop in the samples traits, among others, root and stem length and their fresh and dry weights. Although hopbush seeds of the control treatment could germinate at $50 \mathrm{dS} \mathrm{m}^{-1}$ 
salinity level, root and stem growth was completely terminated at salinity levels above $15 \mathrm{dS} \mathrm{m}^{-1}$, and thus the mentioned factors were not measured. This is while the applied rhizobacterial inocula could, both in individual and combined forms, withstand salinity levels of up to $50 \mathrm{dS} \mathrm{m}^{-1}$, which can be attributed to the increased uptake of nutritive elements by the root system and compatibility with salinity stress and/ or production of growth-promoting hormones by the used bacterial strains present in hopbush. As stated, at $20 \mathrm{dS} \mathrm{m}^{-1}$, the treatments inoculated with Pseudomonas putida and the combination of Azospirillum lipoferum + Azotobacter chroococcum + Pseudomonas putida showed the highest values of the studied early growth parameters, which is in line with the results reported by Fu et al. (2010), YAO et al. (2010), and Hamaour et al. (2001). Fu et al. (2010) reported the increased dry weight and root length of Solanum melongena seedlings inoculated by bacterial strains under salinity stress. Similar results have been reported by YAO et al. (2010) studying the effect of Pseudomonas putida Rs-198 bacterium on Gossypium hirsutum L. seedling under salinity stress. These authors found out that the inoculation of the G. hirsutum L. with $P$. putida improved height and fresh and dry weights of the seedlings by $12.7 \%, 30.7 \%$, and $10 \%$, respectively, compared to the control. GRICHKO and GLICK (2001) inform that rhizospheric bacteria, with their potential for ACC enzyme production, could reduce plant ethylene content, and mitigate, in this way, the negative effects of salinity. Other factors such as hormonal balance (BASHAN and De-BASHAN, 2010) and/or enhanced root system development have been reported as the factors responsible for increased resistance of inoculated plants to salinity-induced stress condition. Hamaour et al. (2001) found out that under saline conditions, Azospirillum could significantly increase the number of nitrogen fixating nodules as well as root growth in pea plants, compared to the control.

At 20 and $50 \mathrm{dS} \mathrm{m}^{-1}$, germination rate and percentage in seeds inoculated with Pseudomonas putida and AC + PP showed the highest values, whereas the combined treatment of Azospirillum lipoferum + Azotobacter chroococcum + Pseudomonas putida brought about the lowest mean germination time but the highest seed vigour index compared to the control. KaNCHANA et al. (2014) reported that the maximal vigour index and germination percentage $(99 \%)$ of pepper seed was attained after a combined inoculation of 4 kinds of bacteria: Azospirillum, Pseudomonas, Azotobacter, and Bacillus. Shaukat et al. (2006) stated that some genera of namely Azospirillum, Pseudomonas, and Azotobacter had a positive and significant effect on seed germination and seedling growth. The present research reports that the increase in root and stem fresh and dry weights at 20 and $50 \mathrm{dS} \mathrm{m}^{-1}$ under the studied bacterial inoculations, in particular the combined ones, may be attributed to the compatibility of hopbush with the mentioned biological fertilizers: This indicates that the applied rhizobacterial strains may be classified as plant growth promoting strains with the potential to promote seed germination, plants growth rate and increase, roots formation, and root hairs development.

The obtained results suggest that the observed growth reduction of hopbush shoot and root under salinity stress may relate to the decrease in root colonization as well as in nutritive elements uptake.
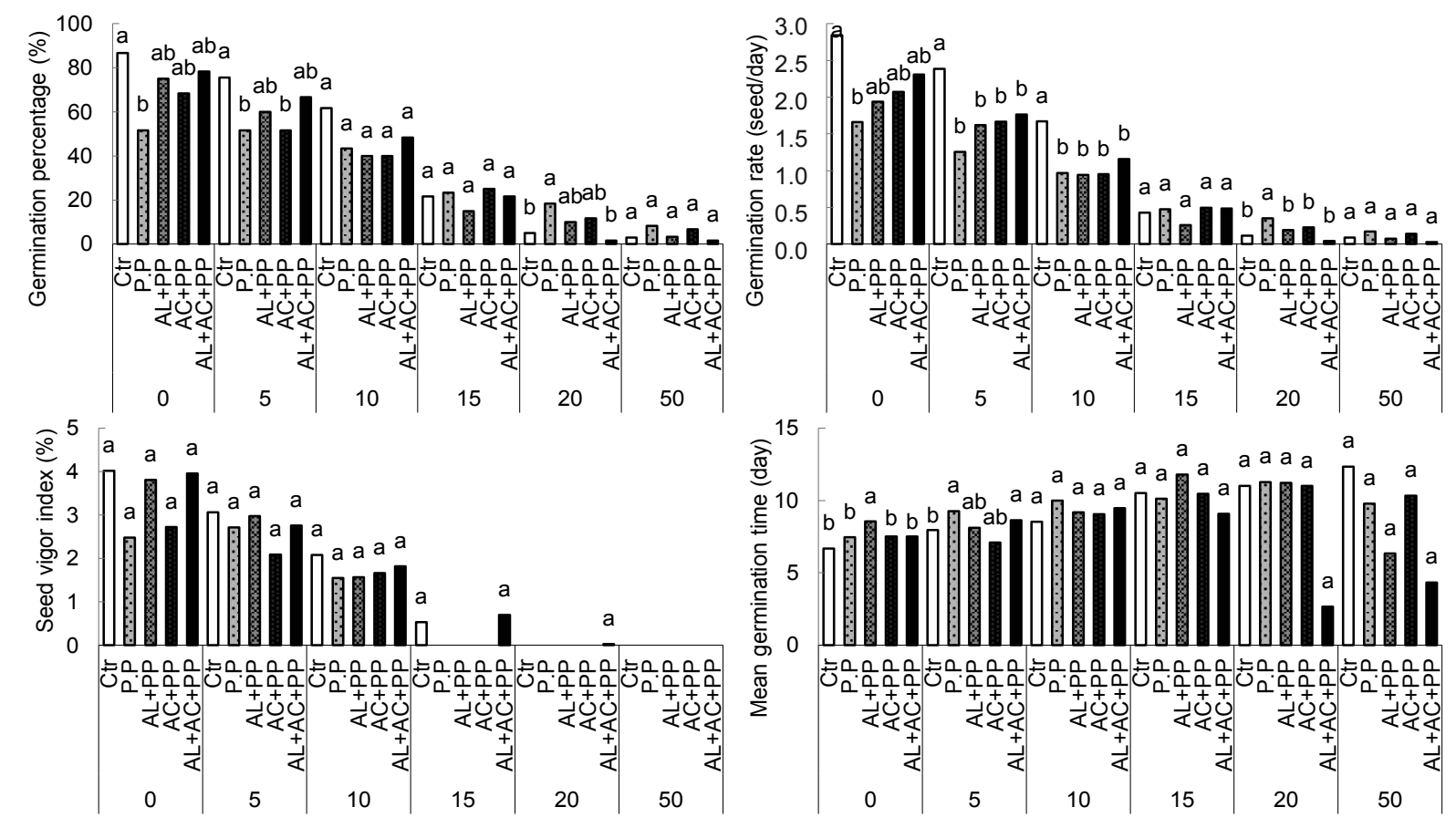

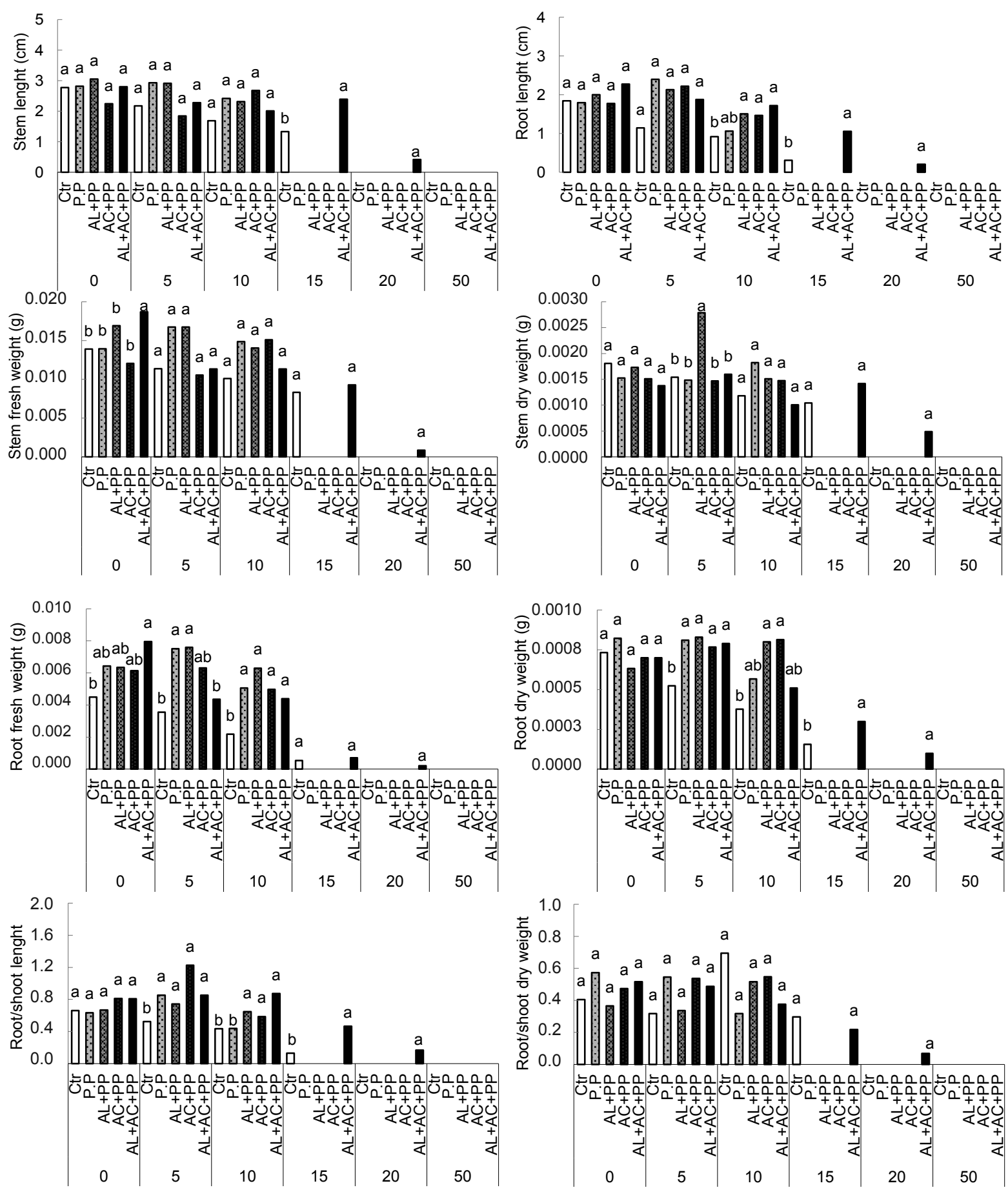

Fig. 1. Mean values of germination and growth characteristics of hopbush seeds inoculated in control conditions with different rhizobacteria under different levels of salinity stress $\left(0-50 \mathrm{dS} \mathrm{m}^{-1}\right)$. Different lower case shows significant differences between bacterial treatments in each level of salinity stress. Ctr, Control treatment; PP, Pseudomonas putida; AL, Azospirillum lipoferum; AC, Azotobacter chroococcum.

The results also revealed that in line with the decrease in the root colonization percentage with bacteria, the plant's growth, performance and resistance declined. In other words, there is a positive relation between root colonization percentage and increase in plant growth and performance.
In summary, application of the rhizobacteria discussed in this study increased and improved growth and resistance in hopbush plants. This indicates that the symbiotic relations between rhizobacteria and plant roots can be profitable for better plant protection against the salinity stress. 


\section{Conclusions}

In the present research, we observed that 20 and 50 $\mathrm{dS} \mathrm{m} \mathrm{m}^{-1}$ salinity stress levels had adverse effects of on growth and germination characteristics of hopbush plants, up to the total growth termination. To compensate the effects of growth reduction at higher levels of salinity stress and, at the same time, to improve the given seed germination characteristics, several growthpromoting bacteria were applied. The results show that the bacteria studied had positive effects on hopbush and that they were also compatible with this plant species. This was particularly evident for the combined treatment. Biological methods (vs. Chemical methods) are more compatible with the physiological characteristics of plants and can effectively reduce the environmental stresses (e.g. drought and salinity, etc.), so using of these bacteria can be objectively recommended as a safe and sound approach.

\section{References}

Abbas-Zadeh, P., Saleh-Rastin, N., Asadi-rahmani, H., Khavazi, K., Soltani, A., Shoary-nejati, A.R., Miransari, M., 2010. Plant growth-promoting activities of fluorescent pseudomonads, isolated from the Iranian soils. Acta Physiologiae Plantarum, 32: 281-288.

Ahmad, M., Mahmood, Q., Gulzar, K., Akhtar, M.S., SAlEem, M., QAdIR, M.I., 2012. Antihyperlipidaemic and hepatoprotective activity of Dodonaea viscosa leaves extracts in alloxan-induced diabetic rabbits (Oryctolagus cuniculus). Pakistan Veterinary Journal, 32: 50-54.

Bashan, Y., De-Bashan, L.E., 2010. Chapter two - how the plant growth-promoting bacterium Azospirillum promotes plant growth - a critical assessment. $A d$ vances in Agronomy, 108: 77-136.

Belimov, A.A., Hotzeas, N., Safronova, V.I., DemChinskaya, S.V., Piluzza, G., Bullitta, S., Glick, B.R., 2005. Cadmium-tolerant plant growth-promoting bacteria associated with the roots of Indian mustard (Brassica juncea L. Czern.). Soil Biology and Biochemistry, 37: 241-250.

Biradar, K.S., Salimath, P.M., Ravikumar, R.L., 2010. Genetic variability for seedling vigour, yield and yield components in local germplasm collections of greeng ram (Vigna radiata (L.) Wilczek). Karnataka Journal of Agricultural Sciences, 20: 608-609.

Fu, Q., LiU, C., Ding, N., Lin, Y., Guo, B., 2010. Ameliorative effects of inoculation with the plant growth-promoting rhizobacterium Pseudomonas sp. DW1 on growth of eggplant (Solanum melongena L.) seedlings under salt stress. Agricultural Water Management, 97: 1994-2000.
Glick, B.R., Todorovic, B., Czarny, J., Cheng, Z., Duan, J., Mcconkey, B., 2007. Promotion of plant growth by bacterial ACC deaminase. Critical Reviews in Plant Sciences, 26: 227-242.

GrichKo, V.P., GLICK, B.R., 2001. Amelioration of flooding stress by ACC deaminase-containing plant growth-promoting bacteria. Plant Physiology and Biochemistry, 39: 11-17.

Haghighi, M., Da Silva, J.A.T., 2014. The effect of carbon nanotubes on the seed germination and seedling growth of four vegetable species. Journal of Crop Science and Biotechnology, 17: 201-208.

Hamaoui, B., Abbadi, J., Burdman, S., Rashid, A., SARIG, S., OKON, Y., 2001. Effects of inoculation with Azospirillum brasilense on chickpeas (Cicer arietinum) and faba beans (Vicia faba) under different growth conditions. Agronomie, 21: 553-560.

Kanchana, D., JaYANThi, M., Usharani, G., SARANRAJ, P., Sujitha, D., 2014. Interaction effect of combined inoculation of PGPR on growth and yield parameters of Chili var K1 (Capsicum annuum L.). International Journal of Microbiological Research, 5: 144-151.

Kefela, T., Gachomo, E.W., Kotchoni, S.O., 2015. Paenibacillus polymyxa, Bacillus licheniformis and Bradyrhizobium japonicum IRAT FA3 promote faster seed germination rate, growth and disease resistance under pathogenic pressure. Journal of Plant Biochemistry and Physiology, 3: 1-5.

Kulkarni, M.G., Street, R.A., Staden, J.V., 2007. Germination and seedling growth requirements for propagation of Diosscorea dregeana (Kunth) Dur. and Schinz Atuberous medicinal plant. South African Journal of Botany, 33: 131-137.

Munns, R., Tester, M., 2008. Mechanisms of salinity tolerance. Annual Review of Plant Biology, 59: 651-681.

Muthukumran, P., Begumand, V.H., Kalaiarasan, P., 2011. Anti-diabetic activity of Dodonaea viscosa (L) leaf extracts. International Journal of PharmTech Research, 3: 136-139.

Noumavo, A.P., Kochoni, E., Didagbé, O.Y., AdJanohoun, A., Allagbé, M., Sikirou, R., GaChomo, E.W., Kotchoni, S.O., BabA-Moussa, L., 2013. Effect of different plant growth promoting rhizobacteria on maize seed germination and seedling development. American Journal of Plant Sciences, 4: 1013-1021.

Nourmohammadi, K., Rahimi, D., Naghdi, R., KarTOOLINEJAD, D., 2016. Effects of physical and chemical treatments of seed dormancy breaking on seedling quality index (QI) of Caspian locust (Gleditsia caspica Desf.). Austrian Journal of Forest Science, 133: 157-171.

Panwar, P., Bhardwaj, S.D., 2005. Handbook of practical forestry. Jodhpur: Agrobios. 192 p. 
Rahimi, D., Kartoolinejad, D., Nourmohammadi, K., NAGHDI, R., 2016. Increasing drought resistance of Alnus subcordata CA Mey. seeds using a nano priming technique with multi-walled carbon nanotubes. Journal of Forest Science, 62: 269-278.

Rajamanickam, V., Rajasekaran, A., Anandarajagopal, K., Sridharan, D., Selvakumar, K., StePHEN RATHINARAJ, B., 2010. Anti-diarrheal activity of Dodonaea viscosa root extracts. International Journal of Pharma and Bio Sciences, 1: 182-185.

Saleem, M., Arshad, M., Hussain, S., Bhatti, A.S., 2007. Perspective of plant growth promoting rhizobacteria (PGPR) containing ACC deaminase in stress agriculture. Journal of Industrial Microbiology and Biotechnology, 34: 635-648.

Sengupta, C., Bhosale, A., Malusare, S., 2015. Effect of plant growth promoting rhizobacteria on seed germination and seedling development of Zea mays. International Journal of Research in Advent Technology, Special Issue: National Conference “ACGT 2015”, 13-14 February, 2015: 32-40.
Shaukat, K., Affrasayab, S., Hasnain, S., 2006. Growth responses of Triticum aestivum to plant growth promoting rhizobacteria used as a biofertilizer. Research Journal of Microbiology, 1: 330-338.

Yao, L., Wu, Z., Zheng, Y., KaleEM, I., Li, C., 2010. Growth promotion and protection against salt stress by Pseudomonas putida Rs-198 on cotton. European Journal of Soil Biology, 46: 49-54.

Yousefi, S., KartoolineJad, D., Bahmani, M., NaGHDI, R., 2017. Effect of Azospirillum lipoferum and Azotobacter chroococcum on germination and early growth of hopbush shrub (Dodonaea viscosa L.) under salinity stress. Journal of Sustainable Forestry, 36: 107-120.

Yue, H., Mo, W., Li, C., Zheng, Y., Li, H., 2007. The salt stress relief and growth promotion effect of Rs-5 on cotton. Plant and Soil, 297: 139-145.

Received July 20, 2016 Accepted October 18, 2016 